\title{
THE DYNAMICS OF TOTAL FACTOR PRODUCTIVITY OFMEDIUM AND LARGE MANUFACTURING IN INDONESIA
}

\author{
Ndari Surjaningsih \\ Bayu Panji Permono ${ }^{1}$
}

\begin{abstract}
This paper calculates and decomposes the Total Factor Productivity (TFP) for large and medium scale industry in Indonesia covering the period of 2000-2009. By using Data Envelopment Analysis (DEA) method, the result shows there is a shift of the supporting factors on the growth of TFP on manufacturing sector within the 2 (two) sample period. In the period of 2000-2004, efficiency change becomes the main contributor on the growth of TFP. Whereas in the period of 2005-2009, technical change becomes the main supporting factor of TFP, however it goes along with the growth of negative efficiency change or the decline of the company's catching-up effect ability to adapt with the more advance technology. The grouping of the sample across subsectors, technical change and also efficiency change shows the declining amount of manufacture industry with superior productivity. Furthermore, the number of low and weakening catching-up industry is increasing.
\end{abstract}

Keywords: Indonesian manufacturing, total factor productivity, technical change, efficiency change, economic scale change, Data Envelopment Analysis

JEL Classification: L6, M11

1 Authors are researcher on Economic Research Group - DKM Bank Indonesia. The views on this paper are solely of the authors and does not necessarily represent the views of Bank Indonesia; corresponding author: email here please. 


\section{INTRODUCTION}

Sector of manufacturing in Indonesia is a strategic at least because of four reasons. First, this sector is the largest contributor in Indonesian Gross Domestic Product (GDP). The segment of this sector in GDP 2011 contributed 24.3 percent. Second, this sector absorbs high employment, after the farming and the trading, hotel and restaurant, as well as service sectors. Third, this sector is the main contributor in the total non-oil and gas export. About 38 percent of the total export value or about 46 percent from the non-oil and gas total export in 2011 arise from manufacturing sector. Fourth, manufacturing sector has high backward lingkage and forward linkage to other sectors. The linkage of this sector to other sectors, both the backward and the forward linkage are above the average within all sectors.

(\% PDB)

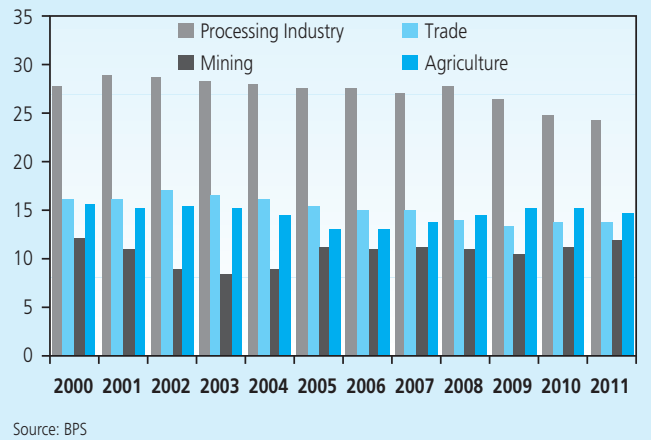

Figure 1.

Manufacturing Sector Segment in GDP
(\%)

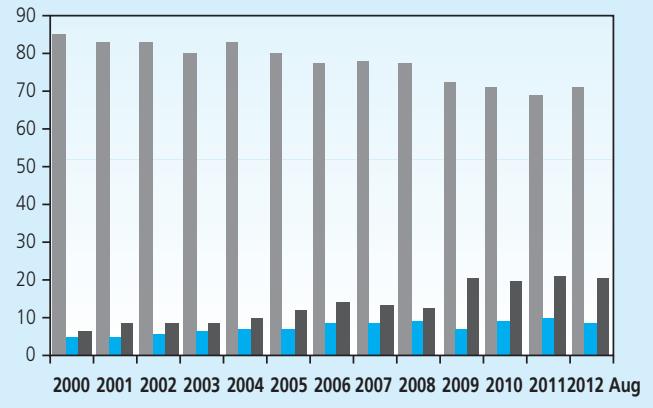

- Processing Industry a Agriculture Mining

Source: Bank of Indonesia

Figure 2.

Non-Oil and Gas Export Structure

\begin{tabular}{l|c|c|c|c|c|c|}
\multicolumn{7}{|c|}{ Table 1 } \\
\multicolumn{1}{|c|}{ Sectorial Labor Segment } \\
\hline \multicolumn{1}{|c|}{ Sector } & $\mathbf{2 0 0 6}$ & $\mathbf{2 0 0 7}$ & $\mathbf{2 0 0 8}$ & $\mathbf{2 0 0 9}$ & $\mathbf{2 0 1 0}$ & $\mathbf{2 0 1 1}$ \\
\hline Farming & 40.14 & 41.21 & 41.33 & 41.61 & 41.49 & 39.33 \\
Trading & 19.22 & 20.55 & 21.22 & 21.95 & 22.49 & 23.40 \\
Industry & 11.89 & 12.37 & 12.55 & 12.84 & 13.82 & 14.54 \\
\hline Source: BPS & & & & & &
\end{tabular}

The growth of manufacturing sector prior economic crisis of 1998 is relatively high $9.2 \%$ (yoy) within the period of 1991-1998. However, the average growth declines after the 1998 crisis, which only reached the amount of 4.6\% (yoy) in 2001-2011. Moreover, since 2004 the 
growth slowed down but started to increase in 2010 and 2011. In general, the contribution of manufacturing sector to economic growth declined in 2004-2009.

$(\%)$

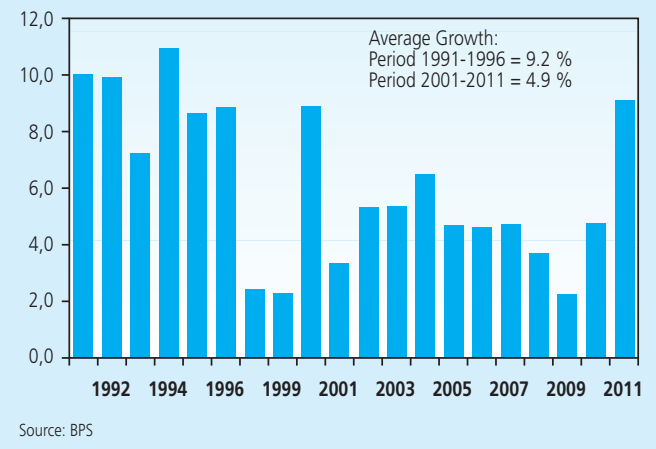

Figure 3.

Manufacturing Sector's Growth

Considering the importance of manufacturing sector above, it is important to further analysis the productivity of this sector, particularly the viability of its output. The use of Total Factor Productivity (TFP) term on this paper includes the productivity of all production factors; hence we do not analyze the productivity of individual factors as commonly found in many literatures.

The first aims of this research is to calculate the Total Factor Productivity (TFP) of the large and medium scale manufacturing companies in Indonesia; second, this paper will identify the determinant of manufacturing productivity; and third, to analyze the technical change and the efficiency change at subsector level. With these aims, we expect to be able to identify the potential and the risk of manufacturing sector performance, as well as the policy required to support it.

The second section of this paper will discuss on the theory, the third section will discuss on the data and methodology, whereas part four will discuss on the result and analysis. The conclusion will be provided in the fifth section and will close the paper presentation.

\section{THEORY}

\subsection{The Concept of Productivity and Efficiency}

The economic performance of a company can be reflected from the level of its efficiency and productivity, that is the ratio of output towards input. The larger the output to input ratio, the higher the performance of the firm will be. If the production process involves more than 
one input, we need to aggregate the input with certain method and make index in order to calculate the productivity ratio. The same case is required when the company produce multiple outputs. This performance measure is a relative indicator across period or across competitors.

We need to clarify some terms related to productivity and efficiency; and the first one is productivity. Productivity means the ratio of produced output towards the used input. This productivity is reflected in the slope in a certain production point (case of one output $\mathrm{y}$; and one input $\mathrm{x}$ ). As shown in figure 5 . Company $\mathrm{B}$ has higher productivity than Company $\mathrm{A}$.

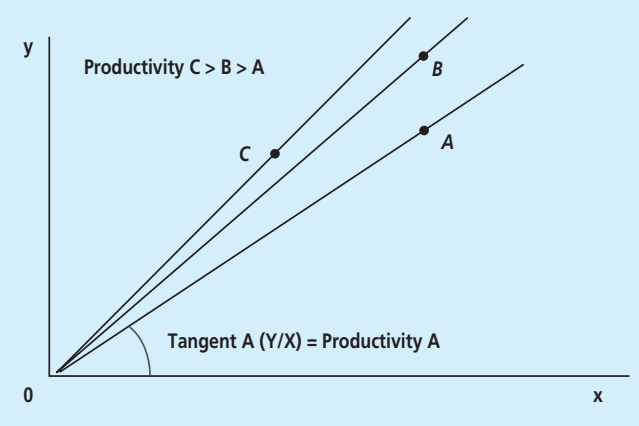

Figure 4.

Illustration of Productivity

The second term is production frontier. The curve of production OF' in Figure 5 shows the amount of maximum output which can be produced in each input level. In other word the production curve reflects the level of the use of technology by the company.

The third term is efficiency. This is a comparison of the output of certain company towards the maximum output produced by other companies using same set of input. The company is considered to be efficient when it operates exactly on the production line (frontier), which

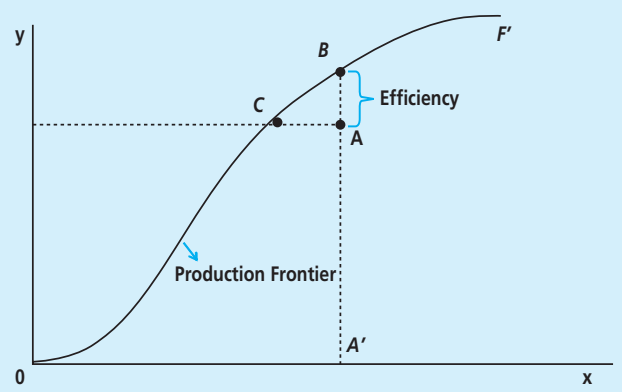

Figure 5.

The Illustration of Efficiency 
is at the point of $B$ and $C$. On the contrary, it is considered to be inefficient if the company operates under its frontier, which is at the point of $A$. At point $A$, the company still can improve its efficiency to point $B$ without additional input. In Figure 5. we can measure the A efficiency of Company $A$ as $A A^{\prime} / B A^{\prime}$.

We can use Figure 6 to distinguish efficiency and productivity. As explained above, the productivity level is depicted by the slope of the straight line from point $\mathrm{O}$. According to Figure 6 , both Company A and B have equal productivity, however, the efficiency Company A is lower than Company B. On the other hand, Company B and C have the same efficiency; however, the productivity of Company $C$ is larger than Company B. Thus, companies who have the same productivity do not necessarily have the same efficiency, and the companies which equal efficiency do not always have equal productivity.

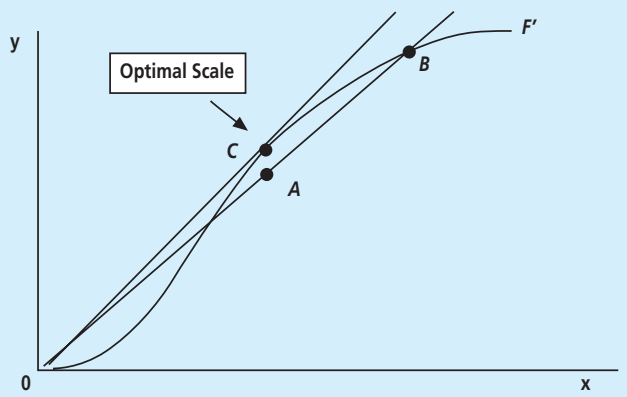

Figure 6.

The illustration of Efficiency and Productivity Comparison

Allocative efficiency is another term. This is a combination of input composition which produces output with minimum cost or yield maximum income. We can measure the allocative efficiency only if we know the value of those inputs cost. We also know the term of technical

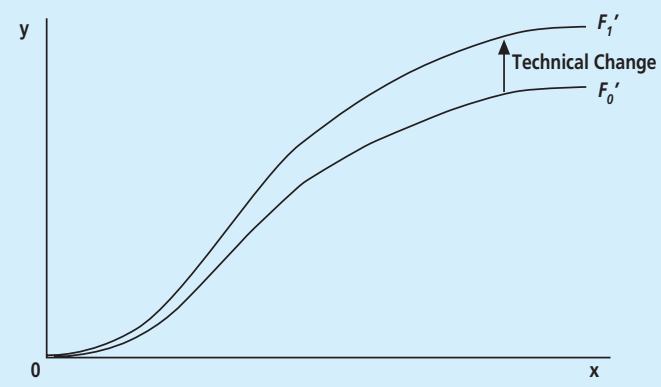

Figure 7.

Illustration of Technical Change 
change, which can be estimated by how much the production frontier shift say from one period to another. Figure 7 shows the technical change shifts from $F_{0}{ }^{\prime}$ to $F_{1}{ }^{\prime}$

Another important term is economies of scale. We can calculate this only if we release the assumption of Constant Return to Scale; hence Variable Return to Scale. The value of economies of scale is the distance between CRSand VRS. Figure 8 illustrates the economies of scale (grey area) which is located between OB curve (Production Frontier under CRS) and OF' (Production Frontier under VRS). The optimal economic scale is the point where the company operates in VRS frontier ( $\left(\mathrm{F}^{\prime}\right)$ with the highest productivity, compared to other companies within the same OF' curve. On this figure, the Company $C$ is in its optimal scale.

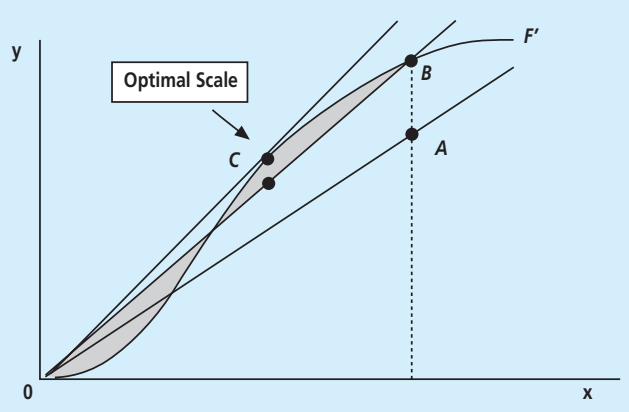

Figure 8.

Illustration of The Economical Scale

The last term to clarify is Total Factor Productivity (TFP). This is a productivity which includes all factors of production ${ }^{2}$ and can be decomposed into efficiency, technical change, and economic scale. Thus, the concept of TFP used on this paper is different from common method that measure TFP from residual (technology) in production function with capital and labor as primary inputs.

\subsection{Productivity and Efficiency Measurement}

We have three options to measure efficiency; input oriented, output oriented, and distance function. Using input oriented measure, we target certain output then minimize the use of input. Within this method, the most essential variable to observe is input. On the other hand, the output oriented method target certain level of input and then maximize the output.

2 Including calculating all of the output in the case of multiple-output production. 


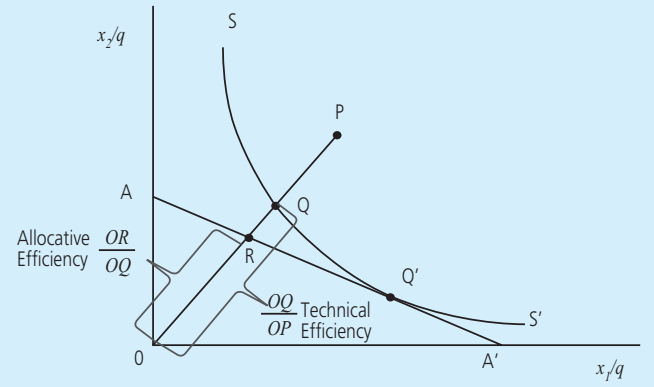

Figure 9. Input Oriented

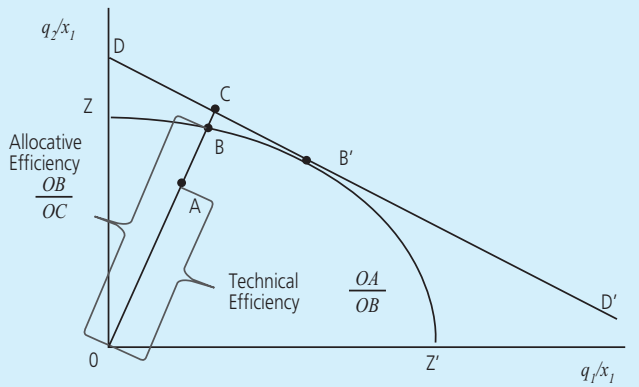

Figure 10. Output Oriented

The third method, distance function, is commonly used on academic literature. Before we explain this method in details, we firstly outline the production technology, which explain the multiple-output production technology. The representation of technology set may refer to Coelli (2005) following Fare and Primont (1995),

Let $S$ be the technology set, while $x$ and $q$ represent $N \times 1$ input vector and $M \times 1$ output vector. The vector value is non-negative real numbers in nature. Technology set below consists of both input and output vectors $(x, q)$ in which $x$ produces $q$.

$$
S=\{(x, q): x \text { can generate } q\}
$$

Production technology can be represented with output and input set as follows::

a) Output Sets, $P(x)$, is an array of output vector, $q$, which can be produced using input vector, $x$. Output set will be our base to construct production possibility curve (PPF) with two output.

$$
P(x)=\{q: x \text { can generate } q\}=\{q:(x, q) \in S\}
$$

b) Input Sets, $L(q)$, is an array of input vector, $x$, which generate certain output vector, $q$.

$$
L(q)=\{x: x \text { can generate } q\}=\{x:(x, q) \in S\}
$$

Without losing generality, we can explain multi-output technology with one input $(x 1)$ and two outputs $\left(q_{1}\right.$ and $\left.q_{2}\right)$. The input is function of these two outputs:

$$
x_{1}=g\left(q_{1}, q_{2}\right)
$$

The combination of two outputs produced by using certain level of input is our production possibility curve (PPC). When the PPC curve is tangential to isorevenue curve, we have the output combination which maximizes the revenue. The optimum point which produce maximum 
revenue is point $A$, where the slope of isorevenue line $(-p 1 / p 2)$ is equal to the slope of PPC curve.

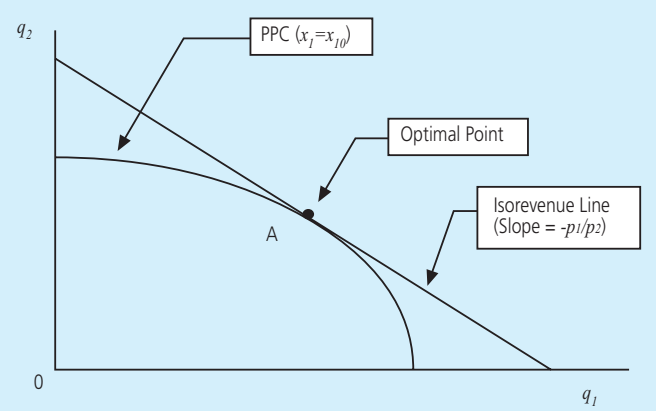

Figure 11.

Production Possibility Curve and Maximum Income

In the case of multiple outputs, technical change may alter the production of certain output relative to other output in two ways. From graphic below, we distinguish between neutral dan non-neutral technical changes.
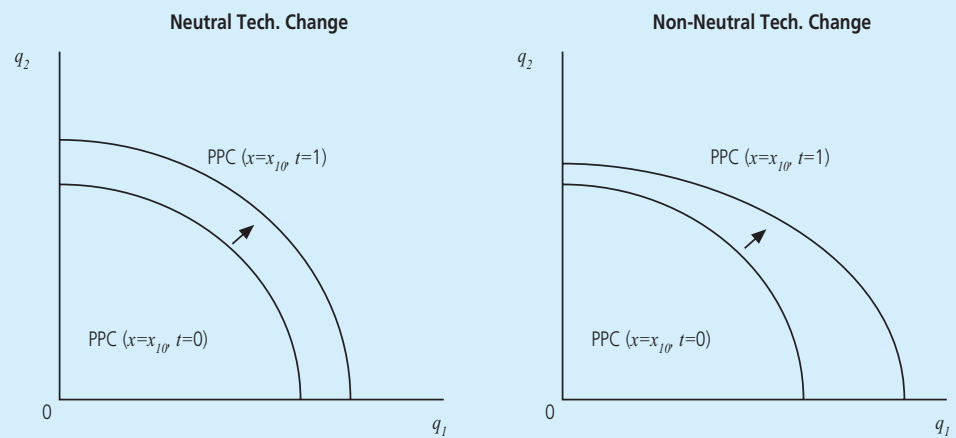

Figure 12. Technical Change Bias and Production Possibility Curve

We can apply the distance function both on output and input. The distance function for a company operating in point $A$ is the ratio of OANOB (see Figure 13 and 14). Distance function equal 1 (one) means the company already operates in PPC which correspond to certain isoquant, $\mathrm{L}(\mathrm{q})$. 


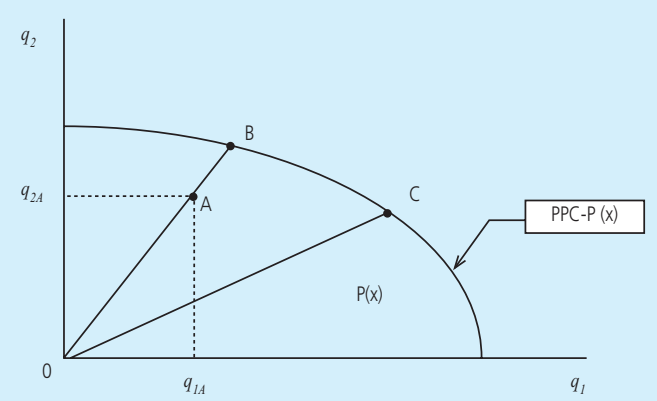

Figure 13. Output Distance Function

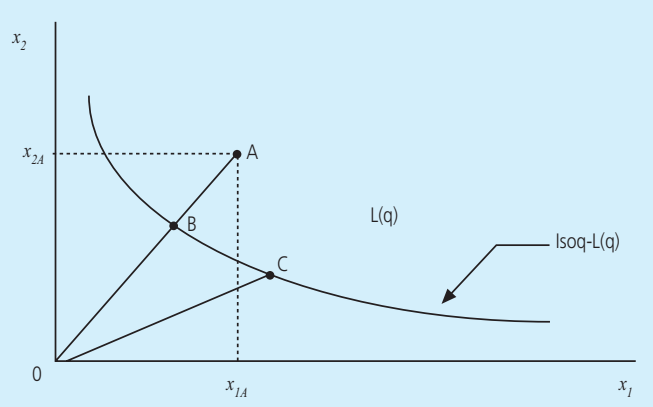

Figure 14. Input Distance Function

\subsection{Malmquist Productivity Index}

The term of productivity in this paper refers to the Total Factor Productivity (TFP) of multifactors and not the partial factor productivity, such as labor productivity or capital productivity. Partial measurement can be misleading when we measure the performance of a company. When a company produces multiple outputs and multiple inputs, we can use the profitability indicator, which is the ratio of total income against total cost from input.

For two companies, the TFP is measured by comparing the profit of the two companies. After using the price of output and input, we can derive a simplified productivity measure as equation below. Here we compare the productivity of the two companies using the real output and the real input.

$$
\frac{\pi_{2}^{*}}{\pi_{1}^{*}}=\frac{q_{2} / x_{2}}{q_{1} / x_{1}}
$$

We can analyze the dynamics of productivity across period. Two periods comparison will involve 2 (two) production technology sets, $\mathrm{S}^{\mathrm{s}}$ and $\mathrm{S}$; , both for period $\mathrm{s}$ and t. Each technology set relates to the vector of output $\mathrm{q}_{\mathrm{s}}$ and $\mathrm{q}_{\mathrm{t}^{\prime}}$ as well as the vector of input $\mathrm{x}_{\mathrm{s}}$ and $\mathrm{x}_{\mathrm{t}}$. Common approach to do this is Malmquist Productivity Index (MPI), and we will apply this method on this paper.

Malmquist Productivity Indexwas firstly introduced by Caves, Christensen and Diewert (1982); a distance function method for representing technology in order to define families of input, output and productivity indexes. For the output produced in period sand period $t$, there is a technology that can produce maximum output using $x_{s}$ and $x_{t}$ input. For example, if company produce $80 \%$ of its maximum capacity using the input vector $x_{s,}$ andin period $t$ he can produce 
output 30\% above maximum capacity using input vector $\mathrm{x}_{\mathrm{t}^{\prime}}$ then the change of productivity from period $s$ to $t$ is $1.30 / 0.80=1.625$.

The calculation of MPI with using the technology reference in period $s$ is:

$$
m_{0}{ }^{s}\left(q_{s}, q_{t}, x_{s}, x_{t}\right)=\frac{d_{o}^{s}\left(q_{t}, x_{t}\right)}{d_{o}^{s}\left(q_{s}, x_{s}\right)}
$$

If the company technically efficient (efficient) in both periods, then $d_{0}{ }^{s}\left(q_{s^{\prime}} x_{s}\right)=1$, thus:

$$
m_{0}^{s}\left(q_{s}, q_{t}, x_{s}, x_{t}\right)=d_{o}^{s}\left(q_{t}, x_{t}\right)
$$

If we calculate MPI using the technology reference in period $t$, we use the following formula:

$$
m_{0}^{t}\left(q_{s}, q_{t}, x_{s}, x_{t}\right)=\frac{d_{o}^{t}\left(q_{t}, x_{t}\right)}{d_{o}^{t}\left(q_{s}, x_{s}\right)}
$$

With both periods MPI in hand, we can calculate the Malmquist TFP Index (MTFPI) as geometrical average from both indexes as follows:

$$
m_{0}\left(q_{s}, q_{t}, x_{s}, x_{t}\right)=\left[m_{0}^{s}\left(q_{s}, q_{t}, x_{s}, x_{t}\right) \times m_{0}^{t}\left(q_{s}, q_{t}, x_{s}, x_{t}\right)\right]^{0.5}
$$

MTFPI can be decomposed to 2 (two) components; efficiency change and technical change. By using output orientated measure, the decomposition of MTFPI is:

$$
M T F P I=\left[\frac{d_{o}^{s}\left(x_{t}, q_{t}\right)}{d_{o}^{t}\left(x_{s}, q_{s}\right)} \times \frac{d_{o}^{t}\left(x_{t}, q_{t}\right)}{d_{o}^{t}\left(x_{s}, q_{s}\right)}\right]^{0.5}
$$

In reality, a company often operates inefficiently, therefore $d_{o}{ }^{s}\left(q_{s^{\prime}} x_{s}\right) \leq 1$ and $d_{o}{ }_{o}^{t}\left(q_{t^{\prime}} x_{t}\right) \leq$ 1. When the company is inefficient, the MTFPI can be calculated as:

$$
\begin{aligned}
& m_{0}\left(q_{s}, q_{t}, x_{s}, x_{t}\right)=\frac{d_{o}^{t}\left(x_{t}, q_{t}\right)}{d_{o}^{s}\left(x_{s}, q_{s}\right)}\left[\frac{d_{o}^{s}\left(x_{t}, q_{t}\right)}{d_{o}^{t}\left(x_{t}, q_{t}\right)} \times \frac{d_{o}^{s}\left(x_{s}, q_{s}\right)}{d_{o}^{t}\left(x_{s}, q_{s}\right)}\right]^{0.5} \\
& \text { Efficiency Change }=\frac{d_{o}^{t}\left(x_{t}, q_{t}\right)}{d_{o}^{s}\left(x_{s}, q_{s}\right)} \\
& \text { Technical Change }=\left[\frac{d_{o}^{s}\left(x_{t}, q_{t}\right)}{d_{o}^{t}\left(x_{t}, q_{t}\right)} \times \frac{d_{o}^{s}\left(x_{s}, q_{s}\right)}{d_{o}^{t}\left(x_{s}, q_{s}\right)}\right]^{0.5}
\end{aligned}
$$


The last MTFPI equation above can be decomposed into 2 components. The first component evaluates the efficiency changes between period s and $t$, while the second component in brackets estimates the changes of technology between the 2 periods.

Figure below illustrate productivity changes measures. It is assumed that a company has a constant return to scale production characteristic with one input and one output. In period $\mathrm{s}$, the company operates in point $\mathrm{D}$ and move to $\mathrm{E}$ point in period $\mathrm{t}$; both points are inefficient. Efficiency and technical change correspondingly are:

$$
\text { EfficiencyChange }=\frac{q_{t} / q_{c}}{q_{s} / q_{a}} \text { and TechnicalChange }=\left[\frac{q_{t} / q_{b}}{q_{t} / q_{c}} \times \frac{q_{s} / q_{a}}{q_{s} / q_{b}}\right]^{0,5}
$$

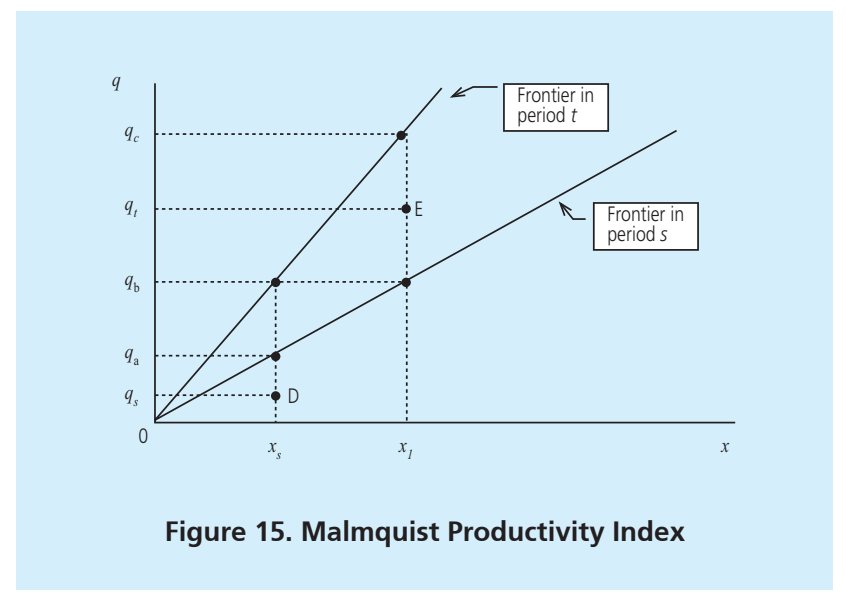

Considering that the calculation of MTFPI is based on CRS assumption, then there are only two sources of productivity growth; efficiency change and technical change. However, under variable returns to scale assumption, along with these two productivity sources, there are also operating scale and efficiency scale. The weakness of MTFPI was covered later by Grifell-Tatje and Lovell (1999) with generalised Malmquist Productivity Index by internalizing the efficiency scale.

\subsection{Data Envelopment Analysis}

Data Envelopment Analysis (DEA) isa data oriented approach, and is used to evaluates the performance of a set of entity called as DMU (Decision Making Units) which convert multiple inputs to multiple outputs. The production frontier estimation with some numbers of homogenous DMU uses non-parametric mathematical programming approach. 
The first frontier estimation with piecewise-linear convex hull approach is pioneered by Farrell (1957). Further development was carried out by Boles (1966) and Afriat (1972) using mathematical programming method on frontier estimation. However, the DEA term become popular after the work of Charnes, Cooper, and Rhodes (1978), who used an input oriented model under Constant Return to Scale (CRS) assumption. After that, Banker, Charnes, and Cooper (1984) modify this model using Variable Return to Scale (VRS) assumption.

Let there are $N$ input and $M$ output for each / companies. Each company is represented by the vector of column $x i$ and qi. The $N x$ input matrix $X$, and $M x /$ output matrix $Q$, represents the data for all of the companies. DEA model uses ratio; for each company, we need to calculate the ratio of aggregate output toward aggregate input. In its aggregation, we use weight where the optimum weight will be determined using mathematical programming. DEA model in the form of Fractional Program (FP) is specified below:

$$
\begin{gathered}
\max _{u, v}\left(u^{\prime} q_{i} / v^{\prime} x_{i}\right), \\
s t u^{\prime} q_{i} / v^{\prime} x_{j} \leq 1 \\
u, v \geq 0 \\
j=1,2, \ldots, I
\end{gathered}
$$

Optimum weight $u$ and $v$ in the FP above is obtained by maximizing efficiency subject to the condition that efficiency value is less than or equal one. The problem arise from the FP above is infinite solutions. Thus, the model in the form of FP above is converted into Linear Programming (LP) as follows:

$$
\begin{gathered}
\max _{\mu, v}\left(\mu^{\prime} q_{i}\right), \\
s t v^{\prime} x_{i}=0, \\
\mu^{\prime} q_{j}-v^{\prime} x_{j} \leq 0, \\
\mu, v \geq 0, \\
j=1,2, \ldots, I
\end{gathered}
$$

The weight notation for FP and LP is distinguished to differentiate its mathematical programming form. We can solve the formulation of DEA model in LP above, however, the constraint will increase as the number of company is, and thuswe need to specify the LP form above into Dual Programming (DP). In dual programming, the number of constraints will not increase following the number of companies but rather only adding the variables to solve. 


$$
\begin{gathered}
\min _{\theta, \lambda} \theta, \\
s t-q_{i}+Q \lambda \geq 0, \\
\theta x_{i}-X \lambda \geq 0, \\
\lambda \geq 0,
\end{gathered}
$$

We can specify the dual-programming using output orientated approach below (remaining of this paper will use this):

$$
\begin{gathered}
\max _{\phi, \lambda} \phi, \\
s t-\phi q_{i}+Q \lambda \geq 0, \\
x_{i}-X \lambda \geq 0, \\
\lambda \geq 0,
\end{gathered}
$$

On the DEA Constant Return to Scale (CRS), it assumes that all of the DMU operates on the optimum economic scale. However, the existence of imperfect competition, financial limitation, etc., make the DMU cannot operate on optimum economic scale. To deal with this we can use DEA model under assumption of Variable Return to Scale (VRS). CRS model is not starkly different with the VRS model except for the addition of convexity constraint $\left(I 1^{\prime} \lambda=1\right)$. Below is the DEA model under VRS assumption:

$$
\begin{gathered}
\max _{\phi, \lambda} \phi, \\
s t-\phi q_{i}+Q \lambda \geq 0, \\
x_{i}-X \lambda \geq 0, \\
I 1^{\prime} \lambda=1 \\
\lambda \geq 0,
\end{gathered}
$$

The economic scale estimated from the above model does not indicate whether the company is increasing or decreasing returns to scale. For this reason we impose a non-increasing return to scale (NIRS) restriction to DEA model. If the technical efficiency in NIRS model is different from technical efficiency in VRS model (TE NIRS $\neq$ TE VRS), then we may conclude it as Increasing Return to Scale (IRS). On the other hand, if the TE NIRS isequal with TE VRS then the case is Decreasing Return to Scale (DRS). 


$$
\begin{gathered}
\max _{\phi, \lambda} \phi, \\
s t-\phi q_{i}+Q \lambda \geq 0, \\
x_{i}-X \lambda \geq 0, \\
I 1^{\prime} \lambda \leq 1 \\
\lambda \geq 0,
\end{gathered}
$$

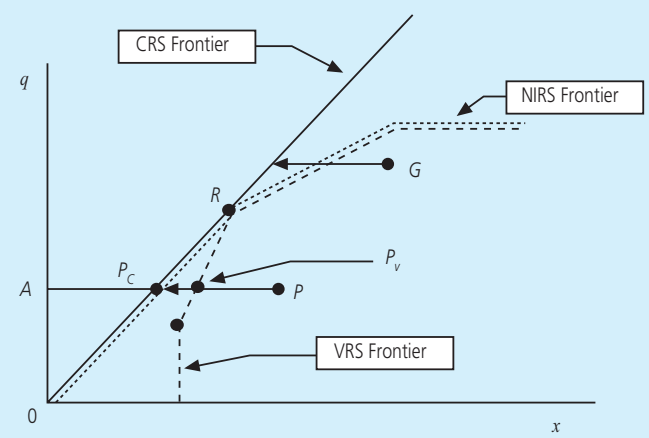

Figure 16. Ilustration on Non-Increasing Returns to Scale

Estimation of dual programming model does not always provide the optimum efficiency point. To ensure the solution of the model provide us optimum efficiency, we can use the following model with slack variable:

$$
\begin{array}{r}
\max _{\lambda, O S, I S}-\left(M 1^{\prime} O S+N 1^{\prime} I S\right), \\
s t-\phi q_{i}+Q \lambda-O S=0, \\
x_{i}-X \lambda-I S=0, \\
\lambda \geq 0, O S \geq 0, I S \geq 0,
\end{array}
$$

$\phi$ is parameter estimated from step one; OS is Mx1 vector of output slacks; IS is Nx1 vector of input slacks; while $M 1$ and $N 1$ are column vector of ones with dimension of $M x 1$ and Nx1 consecutively. 


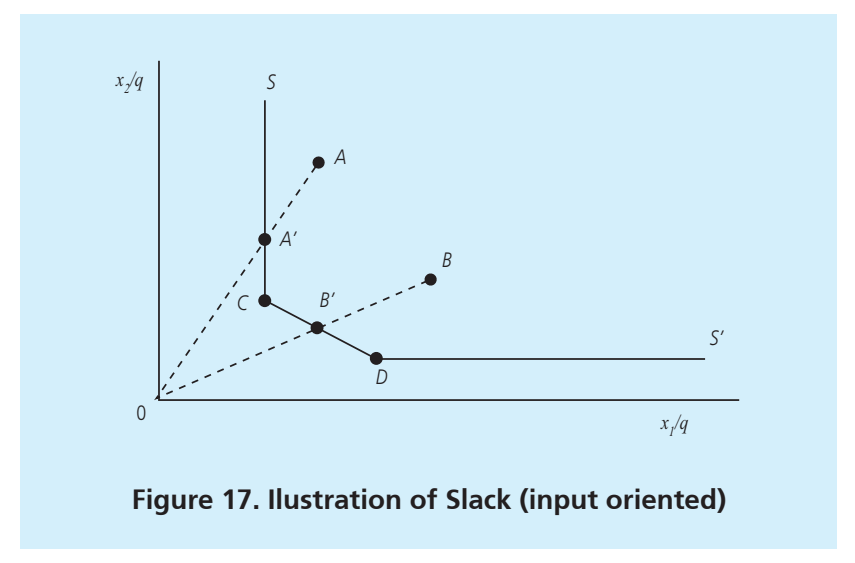

In DEA, the estimation of Total Factor Productivity use index. Simple illustration, if a certain company can produce the same output in period $t$ and $t+1$, but in period $t+1$ only use $75 \%$ of the input period $t$, then the TFP index will increase by $1 / 0.75=1.3$. Similarly, if the company uses the same input in both periods, but produces a $30 \%$ higher output at period $t+1$ compared to period $t$, then the TFP index will be 1.3.

Beside the MTFPI explained in depth above, there are two other TFP index; Hicks-Moorsteen TFP (HM TFP) Index, and TFP Index based on the Profitability Ratio. The earlier illustration use HM TFP index with the following formula:

$$
\text { HMTFP Index }=\frac{\text { Growth in Output }}{\text { Growth in Intput }}=\frac{\text { Output Quantity Index }}{\text { Input Quantity Index }}
$$

However, HM TFP index cannot explain the sources of the productivity growth (technical change, efficiency change), and does not account for the price effect.

On the other hand, the second approach (Profitability Ratio) estimates the TFP index using revenues and costs (price adjusted between period $s$ and $t$ ). Similar with HM TFP index, Profitability Ratio approach also neglect the price effects. For these reason, we will use Malmquist TFP Index (MTFPI).

\subsection{Research on the TFP of Manufacturing sector in Indonesia}

There are some numbers of studies on productivity and efficiency in Indonesia. Generally we can classify those researches based on their approach; Data Envelopment Analysis (DEA) and Stochastic Frontier Approach (SFA). The first approach is non-parametric, while the latter is parametric. 
In the SFA group, Ikhsan (2007) examined the TFP growth and changes in technical efficiency in Indonesian manufacturing industry during the period of 1988-2000. By using Medium and Large Industry Statistic (SIBS), the study concluded that the average TFP growth was 1.55 percent. The contributors of the TFP growth mainly came from technical progress of about 1.89 percent, while the contribution of economic scale and technical efficiency are- $0.13 \%$ and $-0.21 \%$ respectively. On technical efficiency changes, Ikhsan found a visible learning by doing process in technology adoption because the company is not operating at its maximum production capacity.

The National Development Planning Agency or Bappenas (2010) apply Ikhsan method using 2000-2007 data also from SIBS. They found average productivity growth was approximately 0.22 percent. This productivity growth is lower relative to the productivity growth before the crisis 19983. After slowed down during 2000-2004 probably due to post-crisis consolidation, the growth of industrial productivity started to increase 2004-2007.

Bappenas found the major contributor of the productivity increase was technical efficiency growth. On the other hand, the growth of technology and economies of scale contributed negatively to the TFP, respectively $-0.17 \%$ and $-0.45 \%$. In 2-digit level disaggregation in ISIC, the Chemical sector recorded the highest TFP growth by averagely $0.21 \%$ per year, followed by Non-Metallic Mineral sector (0.14\%) and Food and Beverage sectors (0.09\%). The lowest productivity growth was in Wood Industry $(-1.18 \%)$, Other manufacturing $(-0.31 \%)$, and Textiles sector $(-0.08 \%)$.

Prabowo and Cabanda (2011) examined the productivity of Indonesian manufacturing companies listed in Indonesia Stock Exchange 2000-2005 period. Using stochastic frontier approach (SFA), Prabowo and Cabanda found technical inefficiency in the those companies. The average technical eficiency was 0.7149 , showing the company operated below its frontier.

Meanwhile, Saputra (2011) and Halim (2010) examined the productivity of the industrial sector using DEA method. Saputra examine the level of technical efficiency of industrial companies in Indonesia. By using the data in the UNIDO 3-digit ISIC level, they concluded that there are 5 sub-sectors with highest efficiency, Tobacco; Iron and Steel; Transportation Equipment; Non-Ferrous Metal; and Chemistry. In general, the efficiency of basic industry was higher than the traditional industry in the category of low and high-tech industry. Nevertheless, the latter industry showed higher efficiency in the last 2 years of their observation.

Halim (2010) specifically examined the marketing productivity and the profitability of the company in Indonesia. The inputs used in this study were limited to equity and marketing expenses. DEA method was applied to the five categories of industrial manufacturing company listed on the Stock Exchange during 2001 to 2007; Food and Beverage; Clothing and Textile Product; Plastics and Articles of glassware; Automotive Products; and Pharmaceuticals. The

3 Period1988-1992 and 1993-1996. 
main conclusion of this study is the highest productivity of marketing was in 2005-2006, and the major contributor was technological efficiency. A total of 44 companies were identified operating at their efficient level. Based on their categories, Automotive had the highest productivity and technical efficiency. The TFP for efficient company was positively related to Return on Assets (ROA), reflecting the higher efficiency of marketing productivity, the higher financial performance will be.

\section{METHODOLOGY}

\subsection{Methodology}

On this paper, the estimation of TFP growth and its components is based on the Malmquist Indexand the application of DEA-Dual Programming method. The components of Total Factor Productivity include technological changes, change of efficiency and change of economic of scale, across companies, sub-sector, and across year.

Output Oriented Malmquist DEA model can be defined as follows:

$$
\begin{gathered}
\max _{\phi, \lambda} \phi, \\
s t-\phi q_{i}+Q \lambda \geq 0, \\
x_{i}-X \lambda \geq 0, \\
\lambda \geq 0,
\end{gathered}
$$

Where $\varphi$ is a proportional increase in output produced by company $i$, given constant input; $\lambda$ is the weight for each input or output; $q$ is the output of company $i$; and $Q$ is the output of remaining companies. On the other hand, $x$ is the input company $i$, while $X$ is the input for remaining companies.

The Malmquist TFP index is defined as follows:

$$
m_{0}\left(q_{s}, q_{t}, x_{s}, x_{t}\right)=\left[m_{0}^{s}\left(q_{s}, q_{t}, x_{s}, x_{t}\right) \times m_{0}^{t}\left(q_{s}, q_{t}, x_{s}, x_{t}\right)\right]^{0.5}
$$

Furthermore, the components of Total Factor Productivity Malmquist are derived from the breakdown of Malmquist index, as follows:

$$
\begin{aligned}
& \text { Total Efficiency Change }=\frac{d_{o}^{t}\left(x_{t}, q_{t}\right)}{d_{o}^{s}\left(x_{s}, q_{s}\right)} \\
& \text { Technical Change }=\left[\frac{d_{o}^{s}\left(x_{t}, q_{t}\right)}{d_{o}^{t}\left(x_{t}, q_{t}\right)} \times \frac{d_{o}^{s}\left(x_{s}, q_{s}\right)}{d_{o}^{t}\left(x_{s}, q_{s}\right)}\right]^{0.5}
\end{aligned}
$$




$$
\begin{gathered}
\text { Efficiency Change }=\frac{d_{o v}^{t}\left(q_{t}, x_{t}\right)}{d_{o v}^{s}\left(q_{s}, x_{s}\right)} \\
\text { Economic Scale Change }=\left[\frac{d_{o v}^{t}\left(q_{t}, x_{t}\right) / d_{o c}^{t}\left(q_{t}, x_{t}\right)}{d_{o v}^{t}\left(q_{s}, x_{s}\right) / d_{o c}^{t}\left(q_{s}, x_{s}\right)} \times \frac{d_{o v}^{s}\left(q_{t}, x_{t}\right) / d_{o c}^{s}\left(q_{t}, x_{t}\right)}{d_{o v}^{s}\left(q_{s}, x_{s}\right) / d_{o c}^{s}\left(q_{s}, x_{s}\right)}\right]^{0.5}
\end{gathered}
$$

\subsection{Data, Variable, and Proxy}

The main data used in this study is the Survey of Large and Medium (Survei Industri Besar dan Sedang, SIBS) published by the Central Bureau of Statistics (BPS). The period covers 20002009. Each company (KIPN) is grouped based on 3-digit ISIC code. For each company, we use the following set of variables: output, capital, labor, raw materials, and energy.

We can calculate the output of the firm based on their production or sales. This study use the first proxy, since the firm use all resources (capital, labor, raw materials and energy) to produce a number of outputs despite of being sold or stored as inventory. The production value will be deflated using Indonesian wholesale price index correspondingly for each sub sector.

The proxy for capital is estimated fixed or durable asset including land, buildings, machinery, vehicles, and other durable asset. Some missing capital data during the survey is estimated. We use capital at year $t$ to estimate the capital for other years, using the firm investment (purchase or maintenance), the value of sales, and depreciation (assuming equal to $14 \%$ ) during those missing period. To get real capital data, we use Gross Domestic Fixed Capital Formation (GFCF) deflator to deflate the nominal capital.

For employment data, we consider the use of working hours to be appropriate, since same amount of labor in a firm may generate different output when their working hours change (due to overtime or temporary production stops). However, due to a lack of data, this study used the number of workers as proxy for employment.

The intermediate input included raw materials and supporting materials originated both from domestic and import. This intermediate input is deflated using wholesale price index, which is assumed to be equal across companies.

For energy data, we use of fuel and lubricants as well as electricity. Both of these energy were deflated before aggregating them to one energy composite. We deflate fuel and lubricants using their corresponding wholesale price index (premium, kerosene, diesel fuel, diesel oil, fuel oil, and lubricants). For electricity we use sectoral GDP for electricity as deflator.

Our data covers 49 subsectors with the total of 3,295 firms. The summary of variable and the distribution of sample is provided on Table 2 and Table 3. 


\begin{tabular}{|c|c|c|c|}
\hline \multicolumn{4}{|c|}{$\begin{array}{c}\text { Table } 2 \text { Summary of Data Used and Deflator Comparison } \\
\text { Used with the Previous Research }\end{array}$} \\
\hline Variable & SIBS Data Used & $\begin{array}{l}\text { Deflator used in this } \\
\text { Research }\end{array}$ & $\begin{array}{l}\text { Deflator used in Ikhsan's } \\
\text { Research (2007) }\end{array}$ \\
\hline Labor & Numbers of labors & - & \\
\hline Capital & $\begin{array}{l}\text { Fixed capital, includes land, } \\
\text { buildings, machinery and } \\
\text { equipment, vehicles, and } \\
\text { other s }\end{array}$ & $\begin{array}{l}\text { - GFCF in GDP deflator } \\
\text { Usage (BPS) }\end{array}$ & $\begin{array}{l}\text { - Services deflator in the } \\
\text { GDP and IHPB engines } \\
\text { (except electronics), } \\
\text { transportation equipment, } \\
\text { building residential and } \\
\text { non-residential (BPS) }\end{array}$ \\
\hline $\begin{array}{l}\text { Raw } \\
\text { Materials }\end{array}$ & $\begin{array}{l}\text { Raw and Auxiliary Materials, } \\
\text { both domestic and imported }\end{array}$ & - IHPB Total (BPS) & $\begin{array}{l}\text { - IHPB import for raw } \\
\text { materials importinput } \\
\text { (BPS) }\end{array}$ \\
\hline Energy & $\begin{array}{l}\text { - Fuel and Lubricants } \\
\text { (includes: Gasoline, Diesel, } \\
\text { kerosene, coal, gas, LPG, } \\
\text { lubricants, and other fuel); } \\
\text { - Electric Power (Net) }\end{array}$ & $\begin{array}{l}\text { - Fuel and lubricants: IHBP } \\
\text { Solar (BPS) } \\
\text { - Electricity: Electricity Sector } \\
\text { Deflator in the GDP Offers } \\
\text { (BPS) }\end{array}$ & $\begin{array}{l}\text { Data electricity and fuel } \\
\text { prices published by the } \\
\text { Ministry of Mines and } \\
\text { Energy }\end{array}$ \\
\hline Output & Production (produced goods) & $\begin{array}{l}\text { - IHBP based on each type of } \\
\text { industry (BPS) }\end{array}$ & - 4 digit IHPB (BPS) \\
\hline
\end{tabular}

\section{Table 3}

Number of Research Samples Subsector Based

\begin{tabular}{|c|c|c|c|c|c|}
\hline KKI 3 & Sub Sektor Industri & Jumlah & KKI 3 & Sub Sektor Industri & Jumlah \\
\hline 151 & Pengolahan\&pengawetan daging, ikan\&minyak makan & 213 & 264 & Barang2 dari semen\&kapur & 33 \\
\hline 152 & Susu\&makanan dr susu & 8 & 265 & Barang dari marmer, batu\&granit & 15 \\
\hline 153 & Penggilingan padi, biji2an\&makanan & 133 & 266 & Barang dari asbes & 7 \\
\hline 154 & Makanan lainnya & 504 & 269 & Barang Galian Bukan Logam Lainnya & 8 \\
\hline 155 & Minuman & 42 & 271 & Penggilingan besi dan baja & 25 \\
\hline 160 & Pengolahan tembakau & 105 & 272 & Penggilingan non-besi & 13 \\
\hline 171 & Pemintalan & 176 & 273 & Pengecoran & 12 \\
\hline 172 & Pertenunan tekstil & 49 & 281 & Konstruksi Bangunan & 20 \\
\hline 173 & Rajut & 38 & 289 & Bahan Bangunan & 116 \\
\hline 174 & Kapuk & 25 & 291 & Alat2 berat & 45 \\
\hline 181 & Pakaian jadi dari tekstil\&kulit & 160 & 292 & Mesin2 & 12 \\
\hline 191 & Barang dari kulit & 26 & 293 & Peralatan rumah tangga & 33 \\
\hline 192 & Alas Kaki & 47 & 311 & Motor\&Mesin Listrik & 10 \\
\hline 201 & Kayu gergajian & 56 & 312 & Panel\&Pengontrol Arus Listrik & 6 \\
\hline 202 & Kayu Olahan & 103 & 313 & Kabel Listrik\&Telepon & 12 \\
\hline
\end{tabular}




\begin{tabular}{|c|c|c|c|c|c|}
\hline \multicolumn{6}{|c|}{$\begin{array}{c}\text { Table } 3 \\
\text { Number of Research Samples Subsector Based Lanjutan }\end{array}$} \\
\hline KKI 3 & Sub Sektor Industri & Jumlah & KKI 3 & Sub Sektor Industri & Jumlah \\
\hline 210 & Kertas & 89 & 315 & Lampu & 6 \\
\hline 221 & Barang dari kertas & 114 & 319 & Peralatan Listrik lainnya & 8 \\
\hline 232 & Pengilangan minyak bumi & 8 & 323 & Radio, Televisi, Alat2 Rekaman Suara \& Gambar & 8 \\
\hline 241 & Bahan kimia & 79 & 331 & Perlengkapan Kedokteran & 7 \\
\hline 242 & Barang2 dr bahan kimia & 140 & 342 & Karoseri Kendaraan Bermotor Roda 4/Lebih & 19 \\
\hline 251 & Karet\&hasil2nya & 117 & 343 & Perlengkapan\&Komp. Kend. Bermotor Roda 4/Lebih & 40 \\
\hline 252 & Plastik\&hasil2nya & 226 & 359 & Sepeda Motor, sepeda\&becak & 31 \\
\hline 261 & Kaca & 11 & 361 & Furniture & 172 \\
\hline 262 & Porselin & 20 & 369 & Pengolahan Lain & 83 \\
\hline 263 & Barang2 dari tanah liat & 65 & & & \\
\hline
\end{tabular}

\section{RESULT AND ANALYSIS}

The first part of this chapter analyzes the aggregate TFP growth, then its decomposition. In addition to analyzing the entire period (2000-2009), we analyze tow period, 2000-2004 and 2005-2009. Analysis on aggregate industry will proceed to a more detail across subsector of the industry. The analysis on technical change and efficiency change in sub sector level is carried out by plotting them into four quadrants.

\subsection{The Agregate TFP of Manufacture Industry}

Averagely the TFP grew by $7.44 \%$ per annum during 2000-2009. The major sources of TFP growth was dominated by the growth of technical change, and then followed by economic scale change, and finally the efficiency change. This result strongly indicate that during the period of 2000-2009, the companies relied more on the use of new technologies and moved toward optimal scale.

\begin{tabular}{|c|c|c|c|c|}
\hline \multicolumn{5}{|c|}{$\begin{array}{c}\text { Table } 4 \\
\text { The Agregate TFP Growth of Industryandlts Component }\end{array}$} \\
\hline Periode & $\begin{array}{l}\text { Total Factor } \\
\text { Productivity Growth }\end{array}$ & $\begin{array}{l}\text { Technical } \\
\text { Change }\end{array}$ & $\begin{array}{l}\text { Efficiency } \\
\text { Change }\end{array}$ & $\begin{array}{l}\text { Economic Scale } \\
\text { Change }\end{array}$ \\
\hline 2000-2009 & 7.44 & 3.86 & 1.71 & 2.25 \\
\hline $2000-2004$ & 7.83 & -3.52 & 8.15 & 6.98 \\
\hline 2005-2009 & 6.89 & 11.20 & -2.19 & -1.12 \\
\hline
\end{tabular}

The TFP growth slowed down in period 2005-2009 compared to the 2000-2004 period. The source of TFP growth in 2000-2004 was efficiency change, while in 2005-2009 the main source of TFP growth was technical change. 
The strong efficiency change in 2000-2004 was associated with ongoing consolidation after the financial crisis 1998. This included the improvement of investment climate to raise the investor's confidence. As the domestic demand and investment activity was weak, the companies improved their productivity by increasing the production efficiency. The company improved the use of intermediate input, improving production layout to shorten the switching between work stations, aligning the workflow across workplaces (the concept of pull systems) to reduce the accumulation of half finished product between work stations, and the application of Lean Manufacturing conceptsto reduce the idle time between work stations. During 20002004, the slowed down technical change means the decline of production frontier, due to the declining production capability of the machines. One possible reason is disturbance on machine replacement as indicated by the low growth of investment (GFCF/PMTB) and the low realization of investment (both FDI and domestic).

In contrast, during 2005-2009 period, technical change play greater role on TFP growth. The average growth rate of investment and the realization of domestic and foreign investment were higher compared to the previous period (Figure 18 and 19). The increase of aggregate investment and the realization of domestic and foreign investment generally bring new technologies.

During this period, though the technical change increased, the efficiency change or catching up effects decreased. Similar studies on productivity in other countries explain the reason for the decline of catching up effect when technical change increaseis the lack of human resource capacity on adapting the new technologies.

The inability to catch-up indicates a low labor competency, either because of the low education and low skill. This weakness may affect the ability of manufacturing sector to operate optimally. In the long run, this may cause the foreign investment in Indonesia is limited to the low technology one.

(\%)

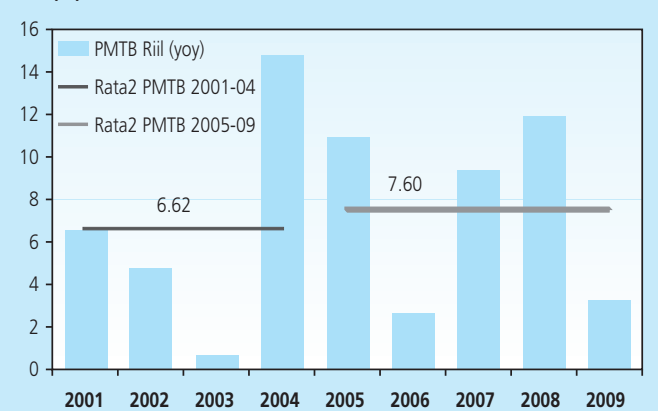

Source: CEIC
(\%)

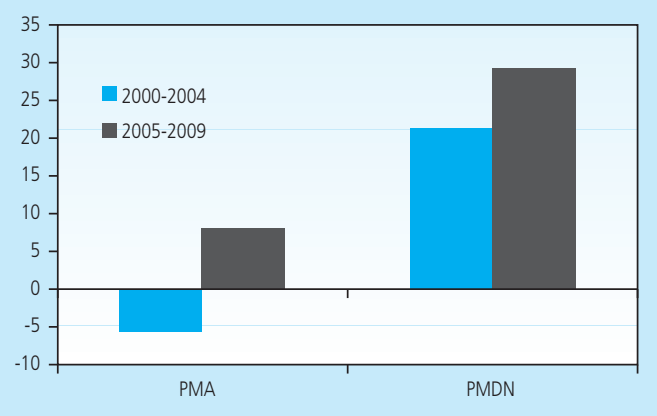

Source Bank of Indonesia

Figure 18.

The Average of PMTB Growth

Figure 19. The Average of foreign (PMA) and Domestic (PMDN) Investment Growth 
Unlike Indonesia, the increase of technical change in Malaysia, was not followed by a decrease in efficiency change (Figure 20). The rank of Global Competitiveness Index during 2012-2013 for Indonesia was apparently far behind Malaysia, especially for the fourth pillar (basic health and education) and fifth pillar (secondary education and training). This may explain the difference of the TFP dynamics over the two economies (Table 5).

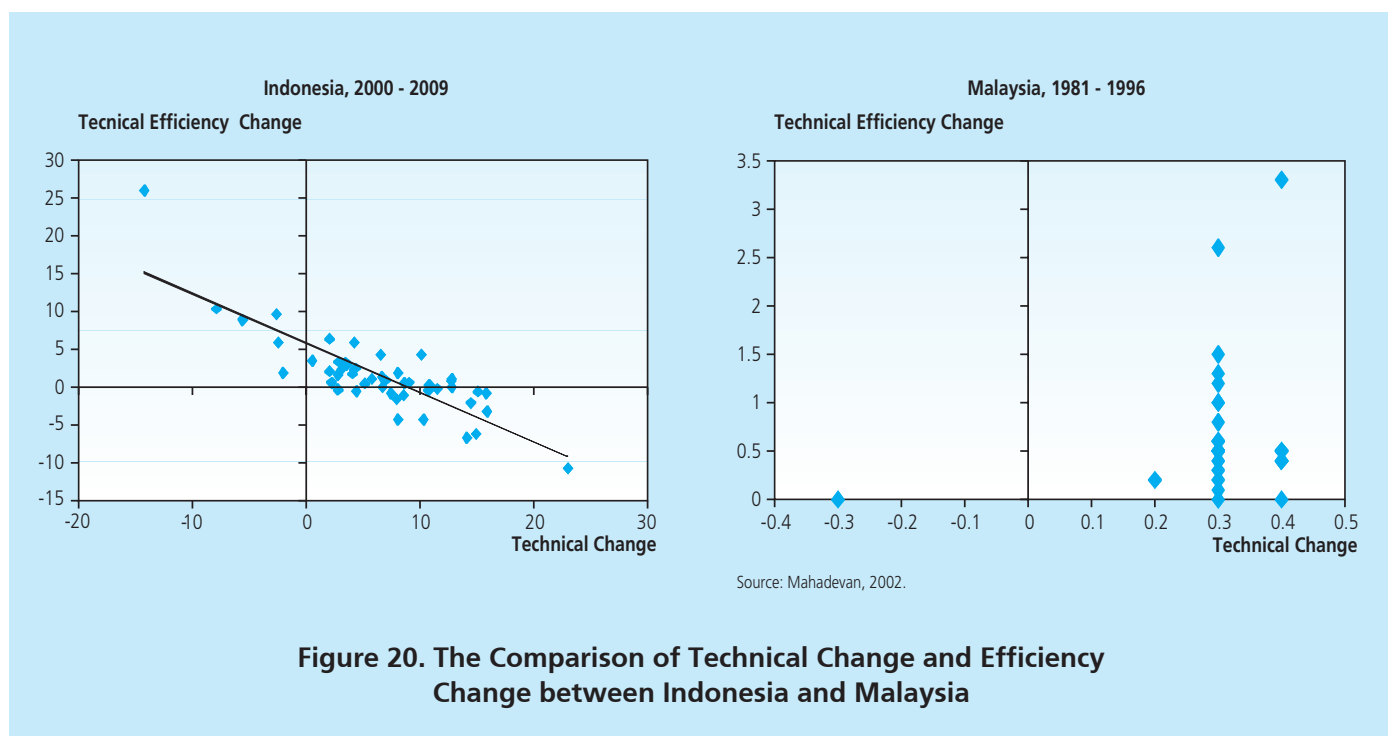

\begin{tabular}{|c|c|c|c|c|c|c|c|c|c|c|c|c|c|}
\hline \multicolumn{14}{|c|}{$\begin{array}{c}\text { Table } 5 \\
\text { Indonesia's Rating based on Global Competitiveness Index 2012-2013 }\end{array}$} \\
\hline $\begin{array}{c}\text { Peringkat } \\
\text { (terhadap } 144 \\
\text { negara) }\end{array}$ & 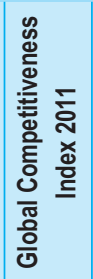 & 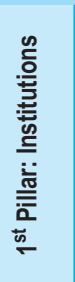 & 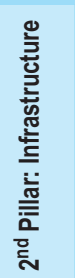 & 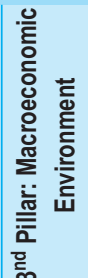 & 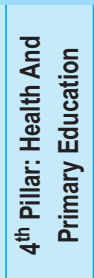 & 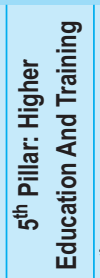 & 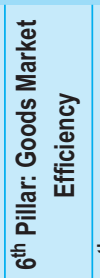 & 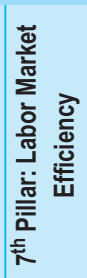 & 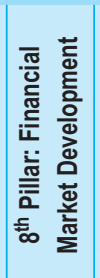 & 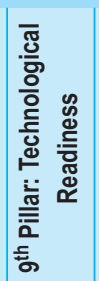 & 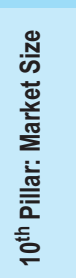 & 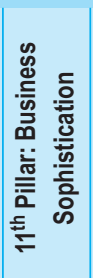 & 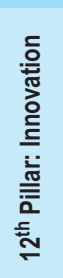 \\
\hline Singapura & 2 & 1 & 2 & 17 & 3 & 2 & 1 & 2 & 3 & 5 & 37 & 14 & 8 \\
\hline Malaysia & 25 & 29 & 32 & 35 & 33 & 39 & 11 & 24 & 6 & 51 & 28 & 20 & 25 \\
\hline China & 29 & 50 & 48 & 11 & 35 & 62 & 59 & 41 & 54 & 88 & 2 & 45 & 33 \\
\hline Thailand & 38 & 77 & 46 & 27 & 78 & 60 & 37 & 76 & 43 & 84 & 22 & 46 & 68 \\
\hline Brazil & 48 & 79 & 70 & 62 & 88 & 66 & 104 & 69 & 46 & 48 & 9 & 33 & 49 \\
\hline Indonesia & 50 & 72 & 78 & 25 & 70 & 73 & 63 & 120 & 70 & 85 & 16 & 42 & 39 \\
\hline Afrika Selatan & 52 & 43 & 63 & 69 & 132 & 84 & 32 & 113 & 3 & 62 & 25 & 38 & 42 \\
\hline India & 59 & 70 & 84 & 99 & 101 & 86 & 75 & 82 & 21 & 96 & 3 & 40 & 41 \\
\hline Filipina & 65 & 94 & 98 & 36 & 98 & 64 & 86 & 103 & 58 & 79 & 35 & 49 & 94 \\
\hline Federasi Rusia & 67 & 133 & 47 & 22 & 65 & 52 & 134 & 84 & 130 & 57 & 7 & 119 & 85 \\
\hline Vietnam & 75 & 89 & 95 & 106 & 64 & 96 & 91 & 51 & 88 & 98 & 32 & 100 & 81 \\
\hline
\end{tabular}




\subsection{TFP and Its Component Across Manufacturing Subsector}

The model calculation show the total factor productivity of all subsectors grew during 2000-2009, except for Lamp industry (Table 6). Technical change became the major source for the growth of TFP in most subsectors (about 75 percent of all 49 subsectors we observed). On the other hand, efficiency change play greater role on the TFP growth in the following subsectors: Spinning; Other foods, Leather goods, Footwear; Glass; Clay product; Building and Construction; Equipment and Components of four or more wheel vehicles; and Other Manufacturing.

Five subsectors with the highest TFP average growth during 2000-2009 are generally classified in high-tech industry. They are Medical Equipment; Other Electrical Equipment; Electric Motors and Engines; Heavy equipment; and Electricity and Telephone Cables. The source of productivity growth for these subsectors is technical change.

\section{Table 6}

The Average TFP Growth and Its Component Based on Industry Subsector, 2000-2009

\section{Sub Sektor Industri}

Pengolahan \& Awetan daging, ikan \& Minyak Makan

Susu \& Makanan dr Susu

Penggilingan Padi, Biji-bijian \& Makanan

Makanan lainnya

Minuman

Pengolahan tembakau

Pemintalan

Pertenunan tekstil

Rajut

Kapuk

Pakaian Jadi dari Tekstil dan Kulit

Barang dari Kulit

Alas Kaki

Kayu gergajian

Kayu Olahan

Kertas

Barang dari Kertas

Pengilangan Minyak Bumi

Bahan Kimia

Barang-2 dr Bahan Kimia

Karet \& hasil-hasilnya

Plastik \& hasil-hasilnya

Kaca

Porselin

Barang2 dari tanah liat

Barang2 dari Semen dan Kapur

Barang dari Marmer, Batu dan granit

\begin{tabular}{|c|c|c|c|}
\hline $\begin{array}{c}\text { TFP } \\
\text { Growth }\end{array}$ & $\begin{array}{c}\text { Technical } \\
\text { Change }\end{array}$ & $\begin{array}{c}\text { Eff } \\
\text { Change }\end{array}$ & $\begin{array}{c}\text { Ec. Scale } \\
\text { Change }\end{array}$ \\
\hline 8,00 & 7,00 & 0,50 & 0,50 \\
\hline 3,00 & 2,20 & $-0,20$ & 1,00 \\
\hline 6,50 & 4,10 & 2,20 & 0,10 \\
\hline 8,50 & 2,00 & 4,50 & 1,80 \\
\hline 10,10 & 8,00 & 0,90 & 1,10 \\
\hline 10,20 & 10,70 & 0,60 & $-1,00$ \\
\hline 8,10 & $-14,30$ & 9,80 & 14,90 \\
\hline 7,70 & 14,90 & $-5,90$ & $-0,40$ \\
\hline 8,20 & 6,60 & 0,70 & 0,70 \\
\hline 9,20 & 8,60 & 1,20 & $-0,70$ \\
\hline 6,60 & 14,10 & $-4,30$ & $-2,40$ \\
\hline 3,40 & $-2,50$ & 1,10 & 4,80 \\
\hline 10,50 & 4,20 & 3,80 & 2,10 \\
\hline 4,40 & 2,70 & 0,20 & 1,50 \\
\hline 4,10 & 2,00 & 3,10 & $-1,00$ \\
\hline 5,80 & 3,10 & 0,50 & 2,10 \\
\hline 9,80 & 23,00 & $-7,20$ & $-3,70$ \\
\hline 7,40 & 8,50 & $-0,20$ & $-0,80$ \\
\hline 5,50 & 10,30 & $-3,20$ & $-1,10$ \\
\hline 6,50 & 7,40 & $-1,30$ & 0,50 \\
\hline 5,90 & 4,00 & 0,60 & 1,20 \\
\hline 6,80 & 6,70 & 0,60 & $-0,50$ \\
\hline 4,20 & 0,50 & 1,60 & 2,00 \\
\hline 7,00 & 5,70 & 0,60 & 0,60 \\
\hline 6,70 & $-2,70$ & 7,80 & 1,70 \\
\hline 6,70 & 3,50 & 0,60 & 2,50 \\
\hline 11,10 & 6,50 & 2,40 & 1,90 \\
\hline
\end{tabular}


Table 6

The Average TFP Growth and Its Component Based on Industry Subsector, 2000-2009 Lanjutan

\begin{tabular}{|c|c|c|c|c|}
\hline Sub Sektor Industri & $\begin{array}{c}\text { TFP } \\
\text { Growth }\end{array}$ & $\begin{array}{c}\text { Technical } \\
\text { Change }\end{array}$ & $\begin{array}{c}\text { Eff } \\
\text { Change }\end{array}$ & $\begin{array}{c}\text { Ec. Scale } \\
\text { Change }\end{array}$ \\
\hline Penggilingan Besi dan Baja & 12,30 & 14,50 & $-1,60$ & $-0,40$ \\
\hline Penggilingan non-besi & 3,90 & 4,40 & $-0,20$ & $-0,30$ \\
\hline Pengecoran & 3,50 & 8,00 & $-3,10$ & $-1,10$ \\
\hline Konstruksi Bangunan & 2,70 & $-5,70$ & 6,80 & 2,10 \\
\hline Bahan Bangunan & 7,00 & 3,40 & 1,40 & 2,00 \\
\hline Alat2 Berat & 13,90 & 12,80 & 1,10 & $-0,10$ \\
\hline Mesin2 & 11,30 & 11,50 & 0,40 & $-0,50$ \\
\hline Peralatan rumah tangga & 7,00 & 4,30 & 0,40 & 2,20 \\
\hline Motor dan Mesin Listrik & 14,40 & 15,10 & 1,10 & $-1,80$ \\
\hline Panel dan Pengontrol Arus Listrik & 13,00 & 12,80 & 0,00 & 0,10 \\
\hline Kabel Listrik dan Telepon & 13,70 & 12,70 & $-0,10$ & 1,00 \\
\hline Lampu & $-0,20$ & $-2,10$ & 0,00 & 2,00 \\
\hline Peralatan Listrik Lainnya & 14,90 & 15,80 & 0,00 & $-0,80$ \\
\hline Radio, Televisi, Alat-2 Rekaman Suara \& Gambar & 11,30 & 10,80 & 0,10 & 0,30 \\
\hline Perlengkapan Kedokteran & 15,00 & 10,10 & 1,00 & 3,30 \\
\hline Karoseri Ranmor Roda 4 Atau Lebih & 9,80 & 9,00 & $-0,80$ & 1,50 \\
\hline Perlengkapan \& Komp. Ranmor Roda 4 Atau Lebih & 6,40 & 2,80 & 3,00 & 0,40 \\
\hline Sepeda Motor, Sepdea dan Becak & 12,20 & 15,90 & $-1,50$ & $-1,70$ \\
\hline Furniture & 2,40 & 2,70 & 0,20 & $-0,40$ \\
\hline Pengolahan Lain & 1,60 & $-8,00$ & 7,20 & 2,90 \\
\hline Weighted Mean & 7,44 & 3,86 & 1,71 & 2,25 \\
\hline
\end{tabular}

\subsection{Subsector Quadrant of Industry and Its Characteristics}

We map subsector of industry into four quadrants based on their level of technical change (high and low ${ }^{4}$ ), and their efficiency change (positive or negative). Quadrant I, includes subsectors with high technical change and positive efficiency change. This quadrant should be for high productivity sub sectors, and are considered as supreme sub sector.

Conversely, quadrant IV cover subsectors with low technical change and negative growth in efficiency change. This quadrant includes those subsectors with low productivity with stagnant progress. Quadrant II is for high technical change sector but with negative efficiency change. This quadrant includes subsector industry with a low ability to catch up. Increasing number of subsectors in quadrant II will indicates the inability for the company to operate efficiently.

4 The cut point for technical change category is its median. 
Our calculation shows that for the period of 2005-2009 (Table 8), the number of subsectors in first quadrant decline relative to previous period, 2000-2004 (Table 7). In contrast, the number of sub-sectors in quadrant II increased across the two corresponding periods. The decreasing number of industry sub-sectors in quadrant I and the growing number of subsectors in quadrant II indicates a lack of development and innovation on managerial (working procedures) along the production process. This affects the firm in two aspects, first, the ability of manufacturing sector to operate at its potential level; and second, the ability of the labor to adapt increasing technology.

The above condition is unfortunate considering the high technical change potentially offer higher productivity. One way to overcome this problem is by developing the skill of the workers to cope with higher technology. 


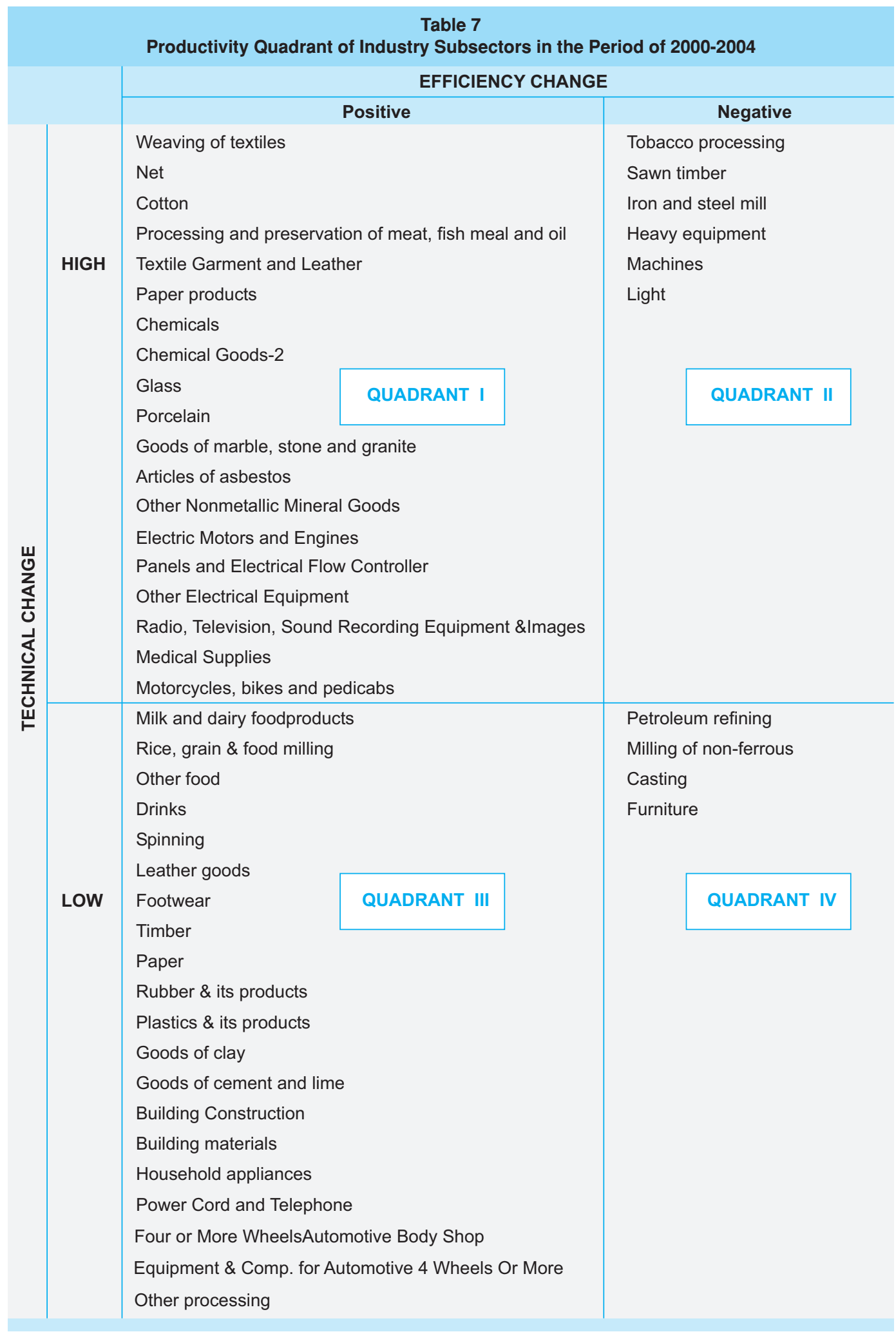




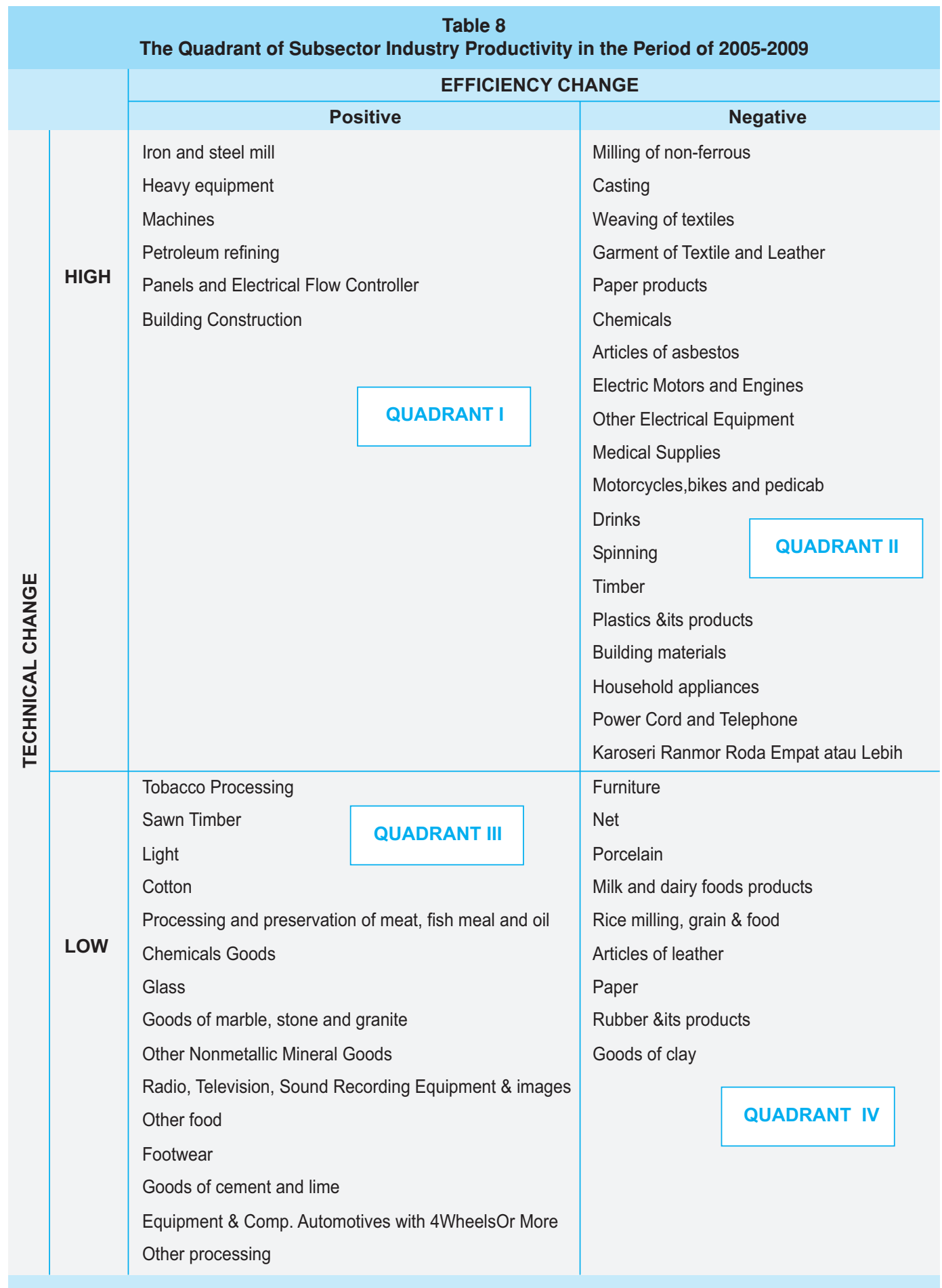


The mapping of subsector onto the four quadrants may depend on the characteristic of the firm within the subsector industry. Some variables gathered from the Survey of Medium and Large Industry (SIBS) include: the intensity of research and development activities (R\&D); innovation; sales orientation; location of the company; the use of foreign investment facility; type of ownership; and years of schooling. These variables are useful to explain our mapping; though it requires formal modeling and statistical testing, which is beyond the scope of this paper.

Table 9 below summarizes the characteristic of the firm within quadrant. We recall that in terms of technical change and efficiency change, quadrant I is better than quadrant II and III, and quadrant II or III is better than quadrant IV. However, apple to apple comparison between quadrant II and III is not valid.

We see some interesting evident from the survey; first, the use of foreign investment facility is associated with higher technical change and also higher efficiency change, which lead them to quadrant I. Second, similar pattern apply when the company is partially or fully owned by foreign. Third, if the company is located in industrial area, the likelihood to have better infrastructure support increase. On the other hand the motivation for companies to learn from each other is greater. These will help them increase their productivity; hence put them more likely in quadrant I, II, then quadrant III.

\begin{tabular}{|c|c|c|c|c|c|c|c|c|c|c|}
\hline \multicolumn{11}{|c|}{$\begin{array}{l}\text { Table } 9 \\
\text { Average Characteristics of Productivity Quadrant }\end{array}$} \\
\hline & \multirow{3}{*}{ Kuadran } & \multirow{2}{*}{$\begin{array}{l}\text { R\&D } \\
(\%)\end{array}$} & \multirow{2}{*}{$\begin{array}{c}\text { Inovasi } \\
(\%)\end{array}$} & \multirow{2}{*}{$\begin{array}{c}\text { Ekspor } \\
\text { Oriented } \\
(\%)\end{array}$} & \multirow{2}{*}{$\begin{array}{c}\text { Kawasan } \\
\text { Industri } \\
(\%)\end{array}$} & \multirow{2}{*}{$\begin{array}{l}\text { Modal } \\
\text { FDI (\%) }\end{array}$} & \multicolumn{3}{|c|}{ Kepemilikan (\%) } & \multirow{2}{*}{$\begin{array}{c}\text { Years } \\
\text { Schooling } \\
\text { (Tahun) }\end{array}$} \\
\hline & & & & & & & Domestik & Asing & Campuran & \\
\hline & & 1 & 2 & 3 & 4 & 5 & 6 & 7 & 8 & 9 \\
\hline \multirow{2}{*}{ I } & HIGH - TECH CHANGE & \multirow{2}{*}{6.3} & \multirow{2}{*}{18.2} & \multirow{2}{*}{17.9} & \multirow{2}{*}{17.9} & \multirow{2}{*}{29.6} & \multirow{2}{*}{68.6} & \multirow{2}{*}{12.0} & \multirow{2}{*}{19.5} & \multirow{2}{*}{10.5} \\
\hline & (+) - EFF CHANGE & & & & & & & & & \\
\hline \multirow{2}{*}{ II } & HIGH - TECH CHANGE & \multirow{2}{*}{5.5} & \multirow{2}{*}{12.4} & \multirow{2}{*}{25.0} & \multirow{2}{*}{11.9} & \multirow{2}{*}{17.2} & \multirow{2}{*}{76.9} & \multirow{2}{*}{12.3} & \multirow{2}{*}{10.9} & \multirow{2}{*}{9.9} \\
\hline & $(-)$ - EFF CHANGE & & & & & & & & & \\
\hline \multirow{2}{*}{ III } & LOW - TECH CHANGE & \multirow{2}{*}{4.5} & \multirow{2}{*}{18.9} & \multirow{2}{*}{22.8} & \multirow{2}{*}{9.1} & \multirow{2}{*}{12.6} & \multirow{2}{*}{84.6} & \multirow{2}{*}{7.3} & & 10 \\
\hline & (+) - EFF CHANGE & & & & & & & & 0.1 & 10.1 \\
\hline IV & LOW - TECH CHANGE & 104 & 179 & 261 & 64 & 104 & 895 & 47 & 58 & 98 \\
\hline IV & (-) - EFF CHANGE & 10.4 & 11.0 & 20.1 & 0.4 & 10.4 & 00.0 & 4.1 & 0.0 & .0 \\
\hline & $\begin{array}{l}\text { n } 1 \text { s.d } 8 \text { berdasarkan } \\
m 9 \text { diperoleh dari rata }\end{array}$ & tase & ah & mpel y & nenjaw & tanya & ang k & & ese & \\
\hline
\end{tabular}




\section{CONCLUSION}

This paper provides several interesting result. First the TFP of medium and large scale companies in Indonesia grew $7.44 \%$ on average during the year of $2000-2009$. The main source of the TFP growth is technical change, followed by economic scale change, and finally efficiency change.

During the period of 2000-2004, the source of TFP growth was efficiency change, while for the period of 2005-2009, the source of TFP growth shifted into technical change, along with the increasing investment activity. This is the second conclusion of this paper.

Third, even though the technical change increased, the catching-up capability (efficiency) decreased in 2005-2009, showing the inability of the company to adapt the more advance technology. 


\section{REFERENCES}

Boediono, DR., "Seri Sinopsis Pengantar Ilmu Ekonomi No. 1 Ekonomi Mikro", BPFE, edisi 2, 1999.

Coelli, Timothy J., et al. (2005), "An Introduction To Efficiency And Productivity Analysis", Springer Science \& Business Media, Inc, edisi kedua.

Coelli T.J. (1996), "A Guide to DEAP Version 2.1: A Data Envelopment Analysis (Computer) Program", Centre for Efficiency and Productivity Analysis (CEPA), Department of Econometrics University of New England, Australia.

Cooper, William W.; Seiford, Lawrence M. and Tone, Kaoru, (2007). "Data Envelopment Analysis", $2^{\text {nd }}$ Edition. Springer.

Direktorat Evaluasi Kinerja Pembangunan Sektoral, (2010), "Perubahan Produktivitas Industri Manufaktur Indonesia dan Faktor-faktor yang Mempengaruhinya: Analisis Panel Data 20002007", Kementerian PPN/Bappenas.

Halim, Rizal Edy, (2010), "Marketing productivity and profitability of Indonesian public listed manufacturing firms: An application of data envelopment analysis (DEA)", Benchmarking: An International Journal, Vol. 17 Iss: 6 pp. 842-857.

Kumbhakar, Subal C. and Lovell, C.A.Knox, (2004). "Stochastic Frontier Analysis". Cambridge University Press.

Ikhsan, Mohamad (2007), "Total Factor Productivity in Indonesian Manufacturing: A Stochastic Frontier Approach", Global Economic Review Vol. 36, No. 4, pp. 321-342.

Mahadevan, Renuka (2002), "A DEA Approach to Understanding the Productivity Growth of Malaysia's Manufacturing Industries", Asia Pacific Journal of Management, 19, 587-600.

Pindyck, Robert S., dan Daniel L. Rubinfeld, "Microeconomics", edisi ke-4, Prentice-Hall, 1998.

Prabowo, Handono E.T., dan Cabanda, Emilyn (2011), "Stochastic Frontier Analysis of Indonesian Firm Efficiency: A Note", International Journal of Banking and Finance, Vol. 8; Iss. 2, Article 5.

Saputra, Putu Mahardika Adi, (2011), "Analysis of Technical Efficiency of Indonesian Manufacturing Industries: An Application of DEA", International Research Journal of Finance and Economics, Issue 66. 